\title{
Evaluation of Bacterial Species to Determine Antimicrobial Resistance in Patients with Chronic Rhinosinusitis after Surgery of Paranasal Sinuses Referring to Amiralmomenin Hospital in Rasht, 2018
}

\author{
Shadman Nemati ${ }^{1}$, Ali Mojtahedi ${ }^{2}$, Soheil Soltanipour ${ }^{3}$, Masoumeh Sharifigar Mavari ${ }^{4}, \underline{\text { Samaneh Rouhi }^{5}}$ \\ 1. Professor, Specialty of Otolaryngology and Head and Neck Surgery, Otorhinolaryngology Research Center, Department of \\ Otolaryngology and Head and Neck Surgery, School of Medicine, Guilan University of Medical Sciences, Rasht, Iran. ORCID \\ ID: 0000-0001-8536-4703 \\ 2. Associate Professor of Medical Microbiology, Cellular and Molecular Research Center, School of Medicine, Guilan \\ University of Medical Sciences, Rasht, Iran. ORCID ID: 0000-0002-5385-9367 \\ 3. Associate Professor of Community Medicine, Eye Research Center, Department of Eye, Amiralmomenin Hospital, School of \\ Medicine, Guilan University of Medical Sciences, Rasht, Iran. ORCID ID: 0000-0001-7768-1121 \\ 4. General Practitioner, Otorhinolaryngology Research Center, Department of Otolaryngology and Head and Neck Surgery, \\ School of Medicine, Guilan University of Medical Sciences, Rasht, Iran. ORCID ID: 0000-0003-0943-3710 \\ 5. PhD of Medical Bacteriology, Medical Microbiology Research Center, Qazvin University of Medical Sciences, Qazvin, Iran., \\ (Corresponding Author), Tel: 028-833790622, Email: roohi.sanmaneh@yahoo.com, ORCID ID: 0000-0003-0160-0924
}

\section{ABSTRACT}

Background and Aim: Bacterial resistance to antibiotics has made treatment difficult. The purpose of this study was to investigate bacterial species in patients with chronic rhinosinusitis after surgery of paranasal sinuses to determine antimicrobial resistance patterns of them.

Materials and Methods: The data of 70 patients after paranasal sinuses surgery in Amiralmomenin hospital in Rasht city, in 2018 were evaluated. The identification of bacteria by microbiological laboratory methods and microbial susceptibility test was performed by disk diffusion method. For data analysis, SPSS version 22 software and chi-square test were used (p $\leq 0.05)$.

Results: $62(88.57 \%)$ positive bacterial culture samples were identified. The most abundant strains was Staphylococcus epidermidis (38.70\%). Staphylococcus aureus had the highest antibiotic resistance to penicillin and oxacillin (52.94\%) and Staphylococcus epidermidis to penicillin (62.50\%). Highest antibiotic resistance in Pseudomonas aeruginosa was to ceftazidime (90.90\%). Escherichia coli was resistant to ceftazidime and ampicillin (100\%) and Hafnia alvei was resistant to ceftazidime (100\%). Klebsiella aerogenes had higher resistant to ceftazidime and cefixime $(100 \%)$. With increasing of patient's age, resistance to antibiotics increased ( $\mathrm{p}$ $\leq 0.05)$.

Conclusion: Antibiotic resistance was observed in bacterial samples isolated from patients after surgery. Given that antibiotic resistance may cause failure in the treatment. Monitoring of the antibiotic-resistant pattern is necessary to select the appropriate antibiotic.

Keywords: Bacterial Species, Antimicrobial Resistance Pattern, Chronic Rhinosinusitis, Paranasal Sinuses

Received: July 27, $2019 \quad$ Accepted: Jan 7, 2020

How to cite the article: Shadman Nemati, Ali Mojtahedi, Soheil Soltanipour, Masoumeh Sharifigar Mavari,

Samaneh Rouhi. Evaluation of Bacterial Species to Determine Antimicrobial Resistance in Patients with Chronic

Rhinosinusitis after sSurgery of Paranasal Sinuses Referring to Amiralmomenin Hospital in Rasht, 2018. SJKU

2020; 25(2): 1-13.

Copyright (C) 2018 the Author (s). Published by Kurdistan University of Medical Sciences. This is an open access article distributed under the terms of the Creative Commons Attribution-Non Commercial License 4.0 (CCBYNC), where it is permissible to download, share, remix, transform, and buildup the work provided it is properly cited. The work cannot be used commercially without permission from the journal 


\title{
بررسى كونههاى باكتريايى و تعيين الكوى مقاومت آنتىبيوتيكى در بيماران مبتلا به رينوسينوزيت مز من بعد از عمل جراحى سينوسهاى يار انازال مر اجعه كننده به بيمار ستان امير المؤمنين (ع)

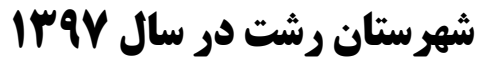

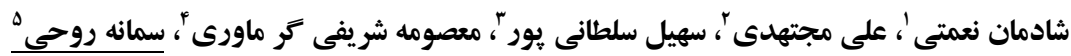

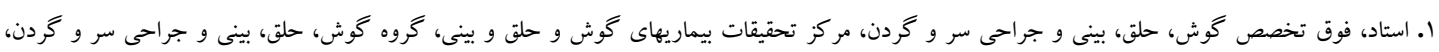

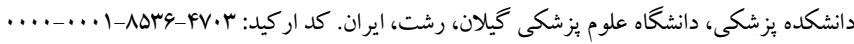

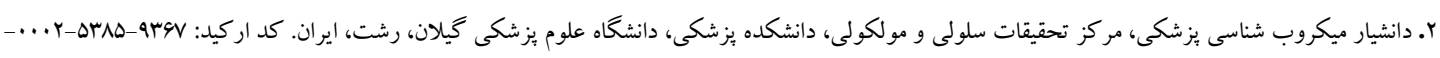

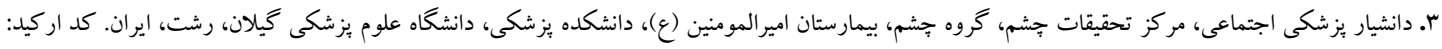

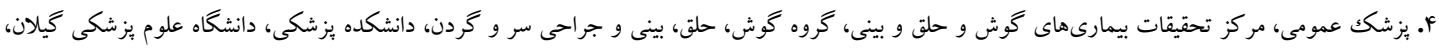

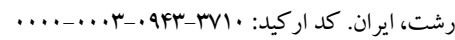

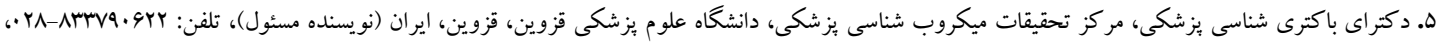
بِ

جكيده زمينه و هدف: مقاومت باكترى به آنتى بيوتيكها درمان را با مشكل مواجه كرده است. هدف از تحقيق حاضر بررسى گونههاى

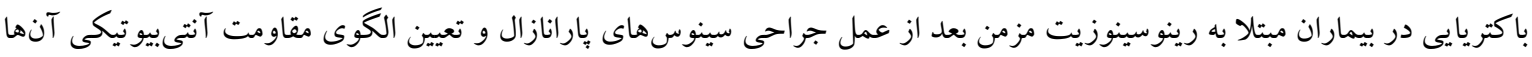
مواد و روشها: اطلاعات ·V بيمار بعد از عمل جراحى سينوسهاى بارانازال در بيمارستان امير المؤمنين (ع) در شهر رشت در سال

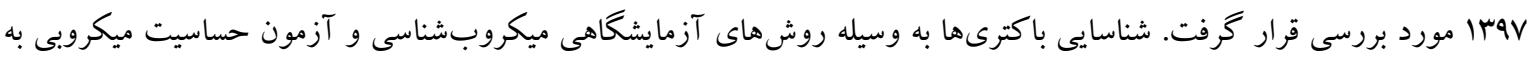

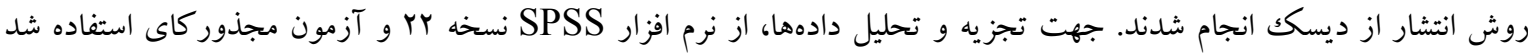
$(\mathrm{p} \leq \cdot / \cdot \Delta)$

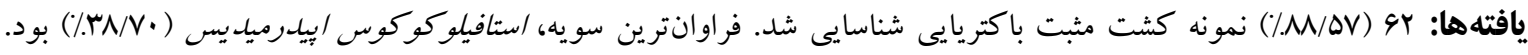

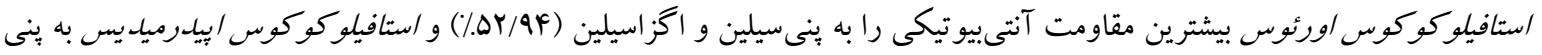

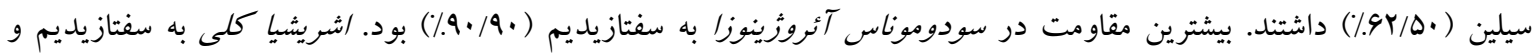

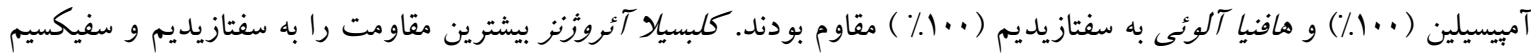

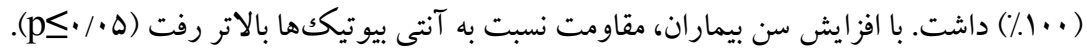
نتيجه كيرى: مقاومت آنتى ييوتيكى در نمونهاى باكتريايى جدا شده از بيماران بعد از عمل جراحى مشاهده شد. اين موضوع ممكن

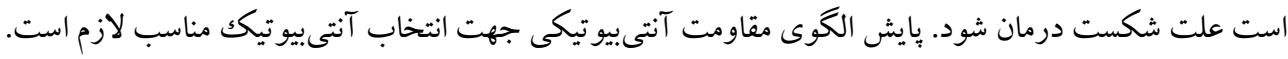

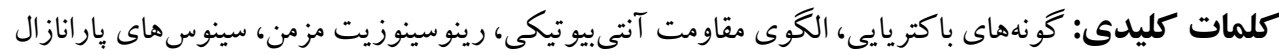

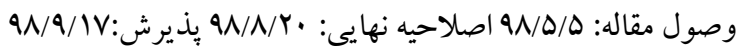


رينوسينوزيت مزمن و مقاوم به درمان دارويى است. اين جراحى زمانى انجام مىشود كه درمانهاى قبلى موفق نباشد و بيمار

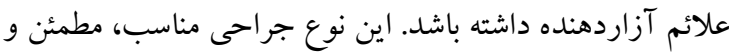
موفق است(Y|،|1). در اين بين درمان رينوسينوزيت مزمن، به دليل افزايش باكترىهاى مقاوم به آنتىبيوتيك با مشكلات مواجه شده است. گزارشهاى اخير ظهور باكترىهاى مقاومت به آنتىبيوتيك در سينوزيت و افزايش فزاينده مقاومت آنتىبيو تيكى و عود مجدد بيمارى را نشان مى دهد(آ). با توجه به افزايش بىرويهى استفاده از آنتىبيوتيككها و مقاومت روز افزون ميكروبها در برابر انواع آنتىبيوتيكهها و مشكلات درمانى ناشى از آنها، وجود اين مشكل در بيماران ممكن است علت افزايش هزينههاى مالى ناشى از درمان، عدم بهبود سلامت

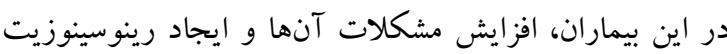

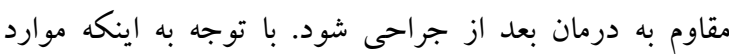

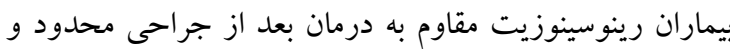
خاص مىباشند، بررسى علل ميكروبى و تعيين بهترين نوع

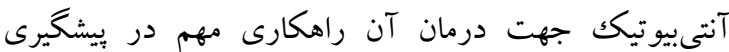
مقاومت آنتىبيوتيكى و درمان سريعتر و كار آمدتر اين بيماران است. لذا هدف از تحقيق حاضر جداسازى و تعيين مقاومت آنتىييوتيكى عوامل باكتريايى دخيل در ايجاد رينوسينوزيت هاريت مزمن پِ از عمل جراحى اندوسكوييك بينى و سينوسهاى

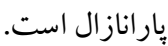

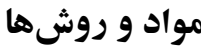

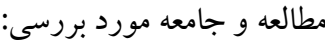
مطالعه ى حاضر بلهورت توصيفى-مقطعى در سال VIraV در

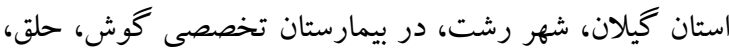
بينى و جشم اميرالمؤمنين (ع) انجام شد. جامعه مورد بررسى شامل تمام افرادى كه مبتلا به رينوسينوزيت مزمن بودند و عمل جراحى آندوسكويى سينوس بپارانازال روى آنها انجام شده بود. براى تعيين حجم نمونه بر اساس درصدهاى مطالعات كذشته جمعيت مورد نظر محاسبه كرديد.

\section{رينوسينوزيت مزمن (Chronic Rhino-Sinusiti (CRS)}

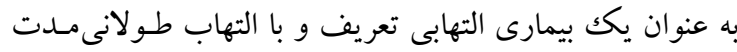
مخاط بينى و سينوس ها مشخص مىشود. اين بيمارى سينوس-

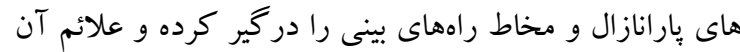
به مدت rا هفته و يا بيشتر طول مى كشد(1). علل آناتوميك (عملكرد قسمتهاى مختلف بدن)، علل عفونى، آلرزىهاى

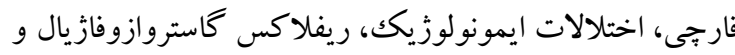
علل زنتيكى از جمله علل ابتلا رينوسينوزيت مزمن است(Y). در

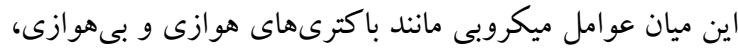
قارجها و ويروسها از مهمترين علل در ايجاد اين نوع بيمارى

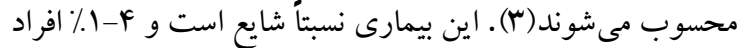

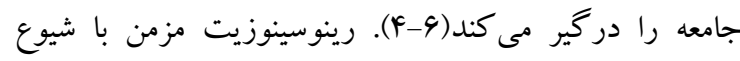

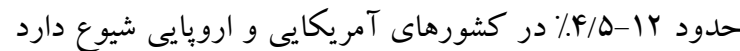
و هزينه سالانه برآورد شده جهت اين بيمارى T/ه/ بيليون دلار تخمين زده شده است(F). اين بيمارى در افراد مبتلا موجب لمان مشكلاتى در تنفس و ساير نقاط بدن مىشود، بر عملكرد روزانه و سلامت روحى افراد نيز تأثير گذار است و كيفيت زند گیى افراد بيمار را نيز با اختلال روبرو مى كند؛ بنابراين درمان آن از اهميت

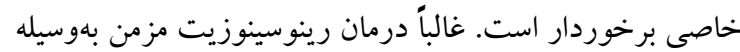
دورههاى تجويز آنتىبيوتيككهاى خـوراكى، آنتىبيوتيكهاى لرهاى موضعى استنشاقى، آنتىهيستامينها، كورتيكواســتروئيدهاى اينترانــازال و نيز شستشـو بـا سـالين هاييرتونيك كه سبب تخفيف نشانهاى رينوسينوزيت مزمن در بيماران مىشود همراه است(ه، (). درمان آنتىبيو تيكى اين بيمارى توسط كو آمو كسىكلاو به عنوان انتخاب اول در درمان رينوسينوزيت باكتريال، كليندامايسين، تركيبى از مترونيدازول و ينىسيلين و مهار كننده بتالاكتاماز يا كينولون (فقط براى بزرگسالان) است (V-9).

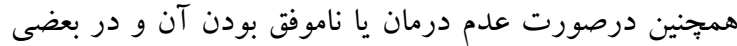

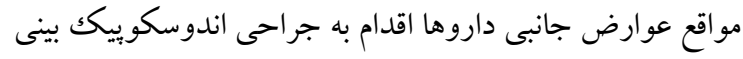

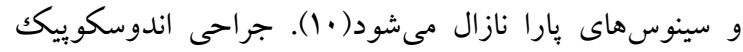

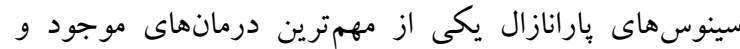

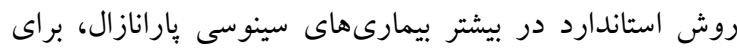

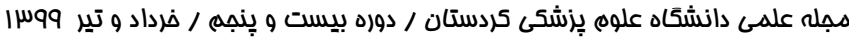


روش نمونهبردارى پِ از انتخاب بيمار، آندوسكويى سينوسى در شرايط استريل بـهـ

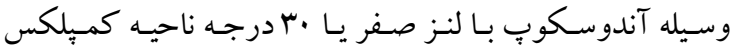

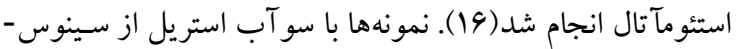

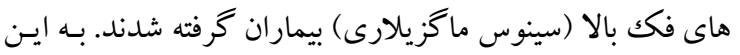
ترتيب كه سو آب از حفره بينى عبور كرده و از طريق مجراى سينوس به نام استيوم تحت كنترل خشـمى وارد سـينوس شـده و سِس مجدد با دقت و به آرامى بيرون كشيده شد(1). دو نمونه سو آب گرفته شد. يك نمونه به محيط انتقالى استوارت (مر ك،، آلمان) و يكك نمونه سو آب از همان بيمار نيـز بـه محيط

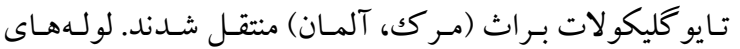

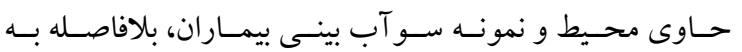

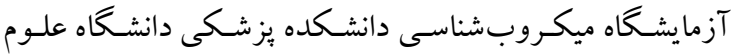

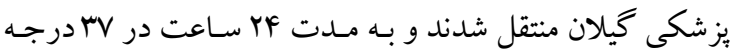
سانتى گر اد جهت رشد و غنى سازى باكترى هاى موجود در در نمونه

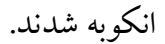
تشخيص نمونههاى باكتريايى تشونه كشت نمونه: نمونهها از محيط انتقالى استوارت روى محيطهـاى

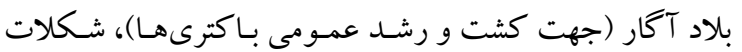
آكار (جهت كشت و رشد عمومى باكترىهايى كه سخت بِسـند هستند و نياز به كلبول قرمز ليز شده دارند)، مكك كانكى آحـار (محيط كشت افتراقى جهـت شناسـايى بـاكترىهـايى بـا تخمير

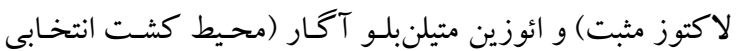

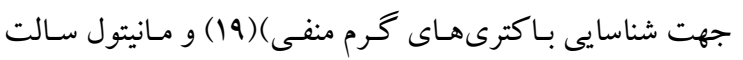
آكار (محيط كشت انتخابى -افتراقى جهت شناسايى باكترىها بـا بـا

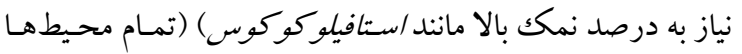

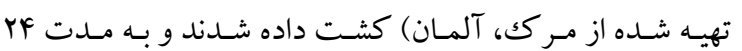
ساعت در WV درجه سانتى گر اد انكوبه شدند( I I). شناسايى باكترىهاى بىهوازى: از محيط تايو كليكولات براث

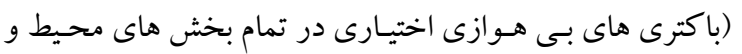

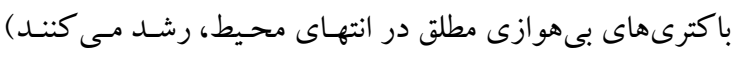
نمونهها روى محيط كشت آكار زرده تخم مرغ (مركى، آلمان)

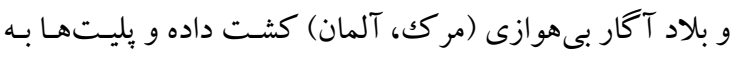

$$
n=\frac{z^{2} p(1-p)}{d^{2}}
$$

حجم نمونه لازم در اين مطالعه جهت بر آورد فاصله اطمينان 9ه٪ d=•// با دقت (Confidence Interval (CI) =•/१८) تعداد •Vف نقر محاسبه شد. نمونه گيرى به روش غير احتمالى از

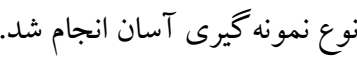

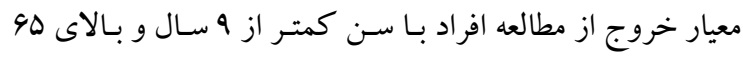

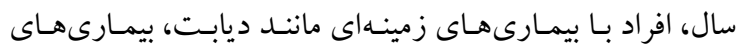

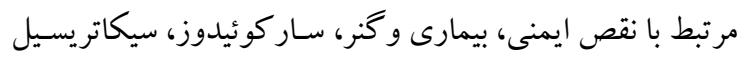

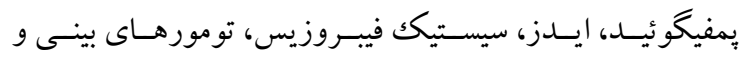

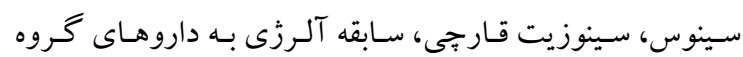

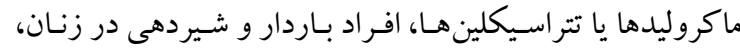

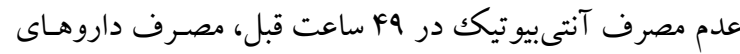

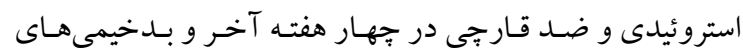

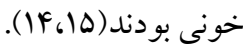
تشخيص رينوسينوزيت مزمن تشخيص بر اساس شواهد بالينى مطرح شده انجام شد. علائم اصلى شامل درد، احتقان يا فشار صورت در قسمت سينوسهاى بلهاى

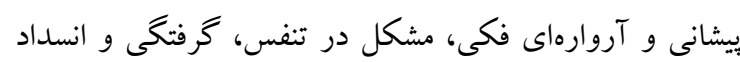

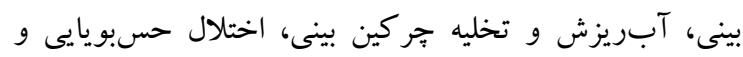
علائم فرعى شامل دردى كم و بيش مبهم در ناحيه بيشانى و و

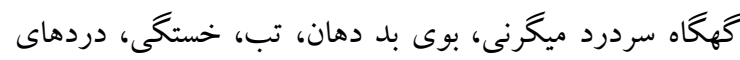

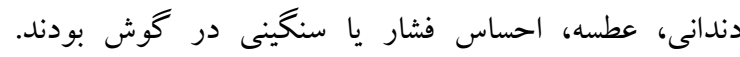

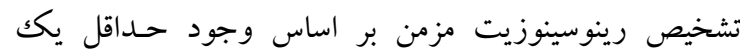
علامت اصلى به همراه دو علامـت فرعى و يـا دو يـا بيشتر از

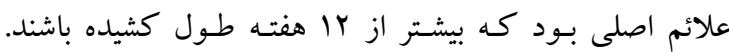

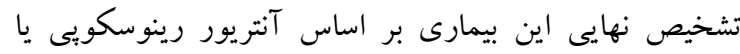

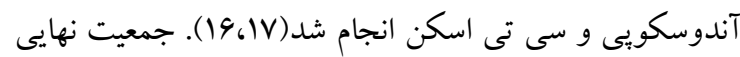

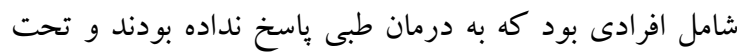
عمل جراحى اندوسكوييك بينى و سينوسهاى بارانازال قرار

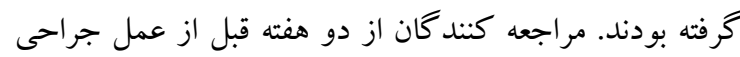
نيز مصرف آنتىبيو تيكك را قطع كرده بودند. 
تلوريت بلاد آكار (مـرك، آلمـان) استفاده شــ. بليـهـا در ه

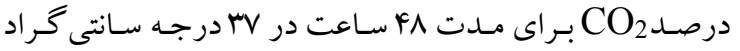
انكوبه شدند. جهت تشـخيص جـنس كورينه از تسـت كاتالاز، Oxidative-Fermentative (OF)

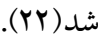

$$
\text { آزمايش آنتىبيو گرام }
$$

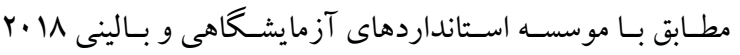
Clinical and Laboratory Standards Institute آنتى بيوتيككهـاى مـورد نظر جهـت آزمايش آنتى (CLSI)

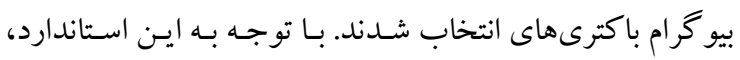

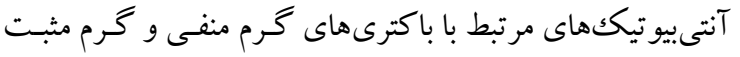

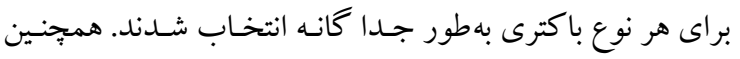
آنتىبيو تيككهايى كه تنها بـه روش minimum inhibitory concentration (MIC) آنتى بيو تيككهايى كه باكترىهاى شناسايىشـده بـه آن مقاومـت ذاتى داشتند در اين تحقيق استفاده نشدند.

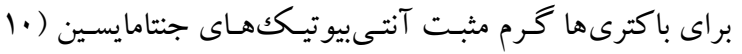

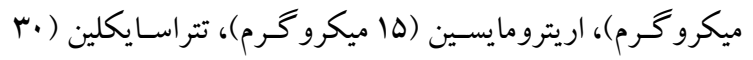

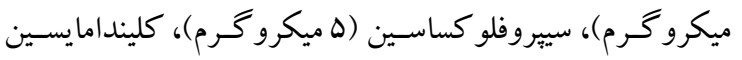

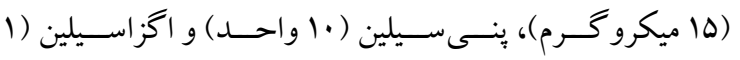

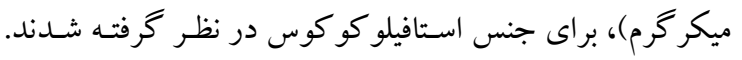

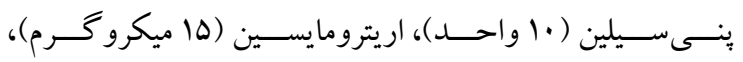

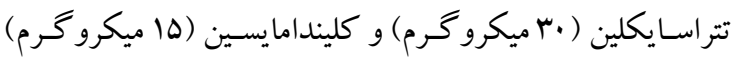

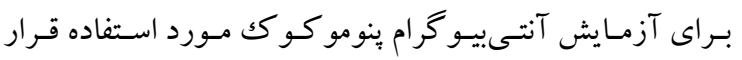

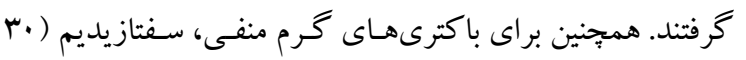

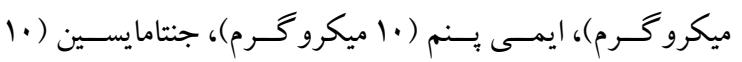

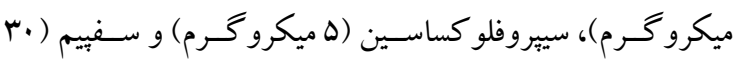

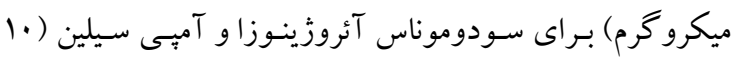

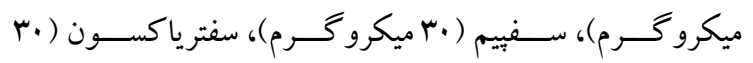

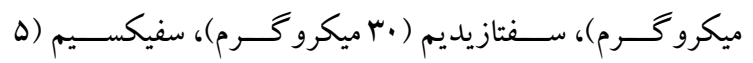

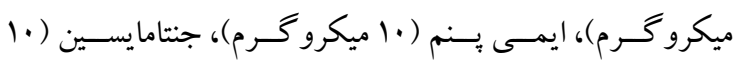

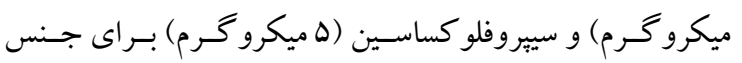

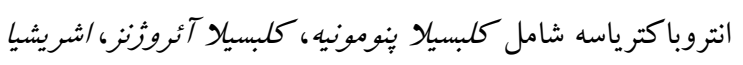

همراه Gaspack (مركى، آلمان) در جار بىهوازى حاوى ه-r

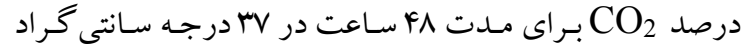

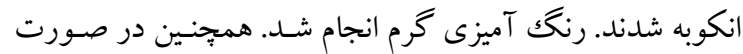
مشاهده باكترى هاى بىهوازى از آزمايشها بيوشيميايى كاتالاز، ليياز، تخمير قندهاى مورد نظر، رشد در بايـل اسكولين، اوره آز

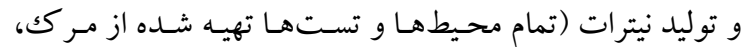

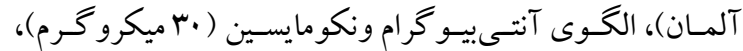

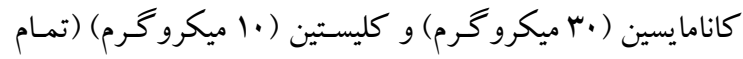

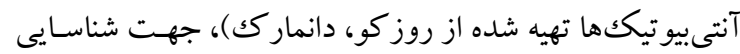

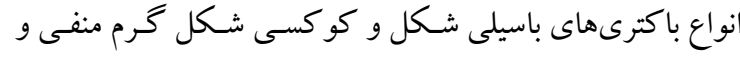
مثبت بى هوازى اجبارى استفاده شد (Y)، · r).

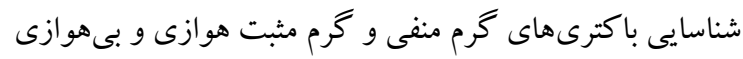

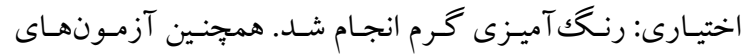

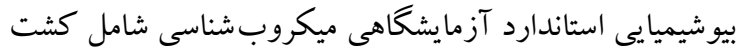

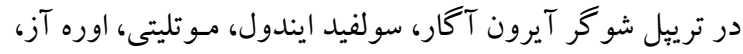

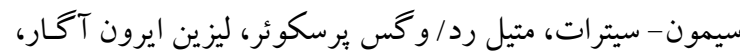
آرزنسين و اورنتسين دكربو كسـيلاز، كاتـالاز و اكسـيداز (تمـام

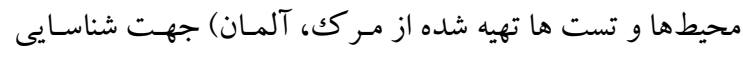

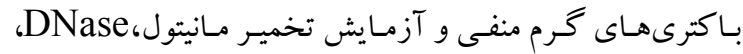

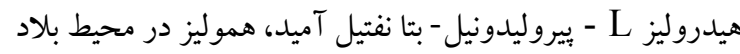
آكار، رشد در نمك ه/ه درصد، تستهاى كاتالاز، اكسيداز و

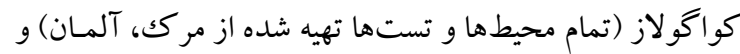

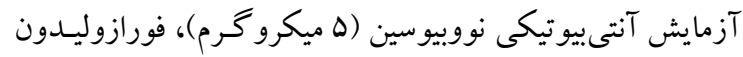

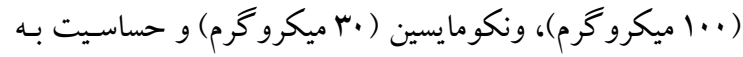

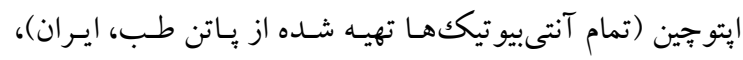
جهت شناسايى باكترىهاى گرم مثبت استفاده شدند( (Y).

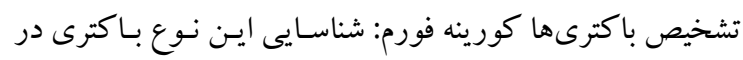

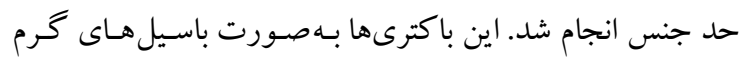

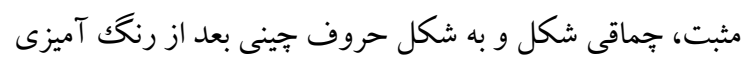

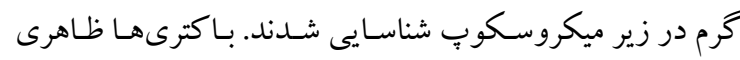

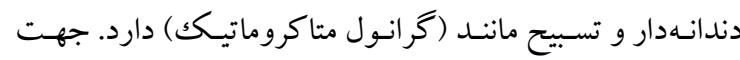

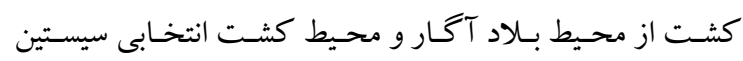


به ينسىسـيلين و اكزاسـيلين (هركـدام 9 سـويه: Fr/9F/\%) داشـت. بيشترين حساسيت حد واسـط در ايسن بـاكترى بـه اريترومايسـين، جنتامايسين و اكز اسيلين (هر كدام ب سويه: IV/AF/) مشاهده شد.

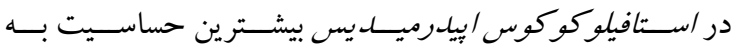

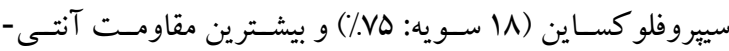

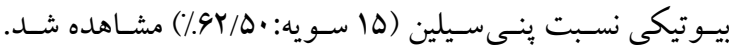
همجينين الكَىى حد واسط در اين باكترى بـه طـور عمـده نسـبت

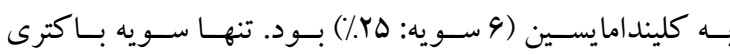
ينوموكوكك نسبت به اريترومايسـين، تتراسـايكلين، وينسىسيلين و كليندامايسين حساس بود و الكَّى مقـاوم و حسد واسط در ايسن سـويه نسـبت بـه هـيج كـدام از آنتىبيو تيـكهــا وجـود نداشـت

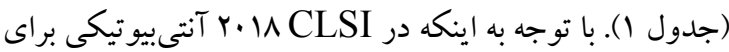
سويه كورينه فرم يافت نشـد، در ايـن مطالعـه بـراى ايـن بـاكترى آزمايش آنتىبيو گر ام انجام نخرفت.

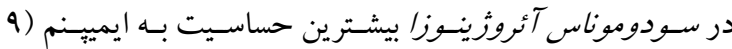

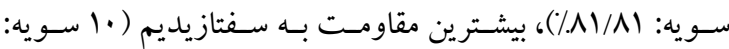

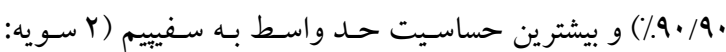
19/99\%) مشـاهده شـد. كلبسـيلا ينومونيه جـدا شـده بـه سـفيم، سفترياكسون، سـتتازيديم، سفيكسـيم، ايمـى يـنم، جنتامايسـين، سيبروفلو كساسين (هر كدام ا سـويه: · 1/) حسـاس بـود. سـويه

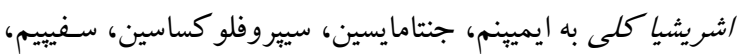
سفترياكسون و سفيكسيم (هر كدام ا سويه: · ' 1٪) حسـاس و بـه

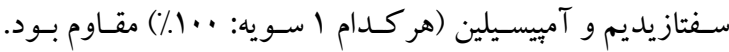
سويه هافنيا آلوئى به ايمى بــنم، جنتامايسـين، سيبروفلو كساسـين،

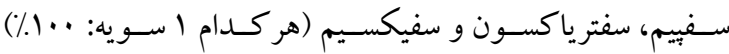
حساس بود؛ امـا بـه سـفتازيديم (1 سـويه: . 1٪) مقــاوم بـود. در مورد كلبسيلا آئروثنـز بيشـترين ميـزان حساسـيت بـه ايمسى بــنم، سيبروفلو كساسين و سفترياكسون (هر ه سويه: . ․ (1) و بيشـترين مقاومت به سفتازيديم و سفيكسيم (هـر ه سـويه: . ․ 1\%) مشـاهده شد. الكوى حد واسط در كلبسيلا ينومونيه، ششريشيا كلى، هافنيا آلوئى و كلبسيل آئروثنز نسبت به هيج يكك از آنتىبيو تيككهاى

مورد استفاده در اين تحقيق مشاهده نشد (جدول Y).
كلسى و هافنيا آلـوئى مـورد استفاده قرار گرفتنـد (تمـام آنتىى بيو تيككها تهيه شده از ياتن طب، ايران). الكوى مقاومست آنتى بيو تيكى باكترىهاى جدا شده از نمونههـاى بـالينى بـا استفاده از آزمون انتشار از ديسكك به روش كربى ــوئر بر اساس موسسـى استانداردهاى كلينيكى و CLSI تعيين شد. در ابتدا سوسِانسيون باكترى كدورت معادل استاندارد ه/ • مكك فارلند آماده و توسط سو آب استريل بهصورت جمنى روى محيط كشت مـولر هينتون آكار (مرك،، آلمان) كشت داده شد؛ سيس ديسكهـاى آنتسى بيوتيكك به فواصل r سانتى متر روى محيط قرار داده و بليتها در

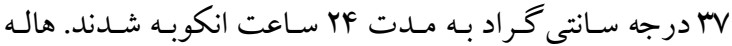
ممانعت از رشد اطر اف ديسك كآنتىبيوتيكك بهوسيله خـط كـش اندازه گيرى شد و با استاندارد CLSI مقايسه و خو انده شد(r). روش آمارى اطلاعات حاصله به وسيله نرمافزار SPSS نسـخه Yr T آنـاليز و بـا استفاده از شـاخصهـاى آمـار توصـيفى و رسـم جـدول فراوانى جهت به دست آوردن درصد مقاومت در باكترىها ارائه شـدند.

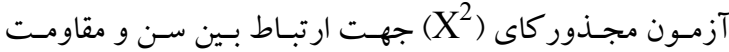
آنتى بيوتيكى مورد استفاده قرار خرفت (ه • /

يافته ها

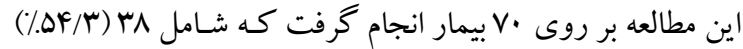

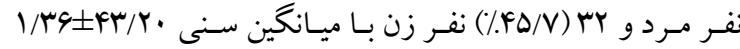

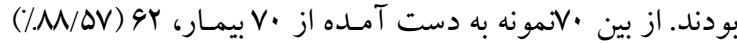

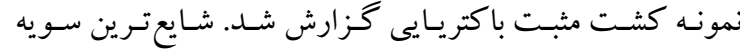

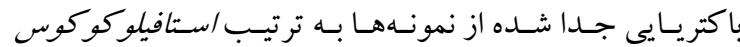

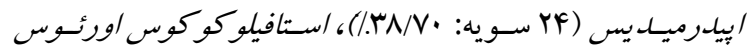
IV) (IV/VF اشريشيا كلى، ينوموكسوك،، هافنيا آلسئى وكورينه فـورم (هـر كدام ا سويه: 1/1/\%) بودند. همجنين نمونهاى كه بـيش از يـك نوع باكترى رشد كرده باشد در نتايج يافت نشد.

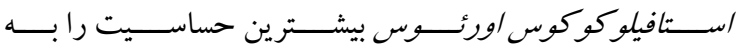

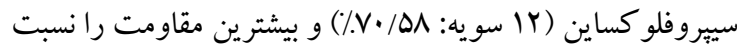


جدول ا. توزيع فراوانى الكوى مقاومت آنتىبيوتيكى در باكترىهاى گرم مثبت در بيماران مبتلا به رينوسينوزيت مزمن به تفكيك آنتىبيو تيك هاى مورد

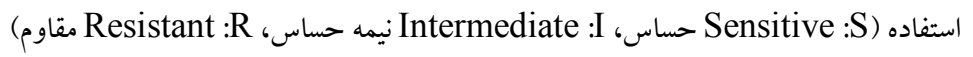

\begin{tabular}{|c|c|c|c|c|c|c|c|c|}
\hline اتزاسيلين & كليندامايسين & ينىسيلين & تتر اسايكلين & سييروفلو كساسين & جنتامايسين & اريترومايسين & 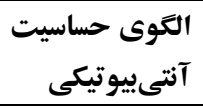 & باكترى كرم مثبت \\
\hline$\Delta$ & 11 & 9 & 9 & ir & 4 & 1. & $\mathrm{~S}$ & \\
\hline$(\% / r q / F 1)$ & $(\% .94 / V \cdot)$ & $(\% / r \Delta / r q)$ & $(\% / \Delta r / Q Y)$ & $(\% \vee \cdot / \Delta \Lambda)$ & $(\% / \Delta \Delta / r q)$ & $(\% / \Delta \wedge / \Lambda Y)$ & & \\
\hline 9 & F & 9 & $\mathrm{v}$ & $r$ & $\wedge$ & f & $\mathrm{R}$ & استافيد \\
\hline$(/ . \Delta Y / Q Y)$ & $(\% / r / \Delta Y)$ & $(\% / \Delta r / Q Y)$ & $(\% \digamma \Psi / / V)$ & $(\% \mid \mathrm{IV} / 94)$ & $(\% \notin V / \cdot \Delta)$ & $(\% / r / \Delta Y)$ & & اورئوس \\
\hline$r$ & $r$ & $r$ & 1 & $r$ & $r$ & $r$ & I & \\
\hline$(\% \mid V / 9 F)$ & $(\% 11 / v 9)$ & $(\% 11 / v 9)$ & $(\% / . / 9)$ & $(\% 11 / \vee 4)$ & $(\% I V / 94)$ & $(\% \mid V / 94)$ & & \\
\hline 9 & $\wedge$ & F & 9 & 11 & 10 & IV & $\mathrm{S}$ & \\
\hline$(\%, r \Delta)$ & (זس/חس/\%) & $(\% 19 / 94)$ & $(\% / r V / \Delta \cdot)$ & $(\% \vee \vee \Delta)$ & $(\% / 9 Y / \Delta \cdot)$ & $(\% \cdot / \wedge r)$ & & \\
\hline if & 1. & 10 & 11 & $\Delta$ & 0 & $\theta$ & $\mathrm{R}$ & \\
\hline$(\% / \Delta N / \Gamma r)$ & $(\% / 41 / 94)$ & $(\% / 9 Y / \Delta \cdot)$ & $(\% \notin \Delta / \wedge \Gamma)$ & $(\% / \Gamma \cdot / \Lambda)$ & $(\% / \Gamma \cdot / \Lambda)$ & $(\% / r \cdot / \Gamma)$ & & 'بيدرميديس \\
\hline F & 9 & $\Delta$ & F & 1 & i & $r$ & I & \\
\hline$(\% 19 / 94)$ & $(\% / r \Delta)$ & $(\% / r \cdot / \wedge r)$ & $(\% 19 / 94)$ & $(\% / / 19)$ & $(\% 19 / 94)$ & $(\% / . / \mu)$ & & \\
\hline \multirow[t]{2}{*}{-} & 1 & 1 & 1 & - & - & 1 & S & \\
\hline & $(\% 1 \ldots)$ & $(\% 1 \ldots)$ & $(\%, \ldots)$ & & & $(\% 1 \ldots)$ & & \\
\hline- & . & . & . & - & - & . & $\mathrm{R}$ & وموكوكى \\
\hline- & . & . & . & - & - & . & I & \\
\hline
\end{tabular}


Sensitive :S) جدول r. توزيع فراوانى الكوى مقاومت آنتىبيوتيكى در باكترىهاى گرم منفى در بيماران مبتلا به سينوزيت مزمن به تفكيك آنتىبيوتيكهاى مورد استفاده حساس، Intermediate :I نيمه حساس، Resistant :R مقاوم)

\begin{tabular}{|c|c|c|c|c|c|c|c|c|c|}
\hline سفيكسيم & سفترياكسون & آميى سيلين & سفِيم & سيِروفلو كساسين & جنتامايسين & ايمى گنم & سفتازيديم & آنتى حساسيت & باكترى كرم منفى \\
\hline- & $\begin{array}{l}- \\
-\end{array}$ & - & $\begin{array}{c}9 \\
(/ \Delta F / \Delta F)\end{array}$ & $\begin{array}{c}9 \\
(/ \Delta F / \Delta F)\end{array}$ & $\begin{array}{c}r \\
(\% / N / / \Lambda)\end{array}$ & $\begin{array}{c}9 \\
(/ \wedge \backslash / \wedge))\end{array}$ & . & $\mathrm{S}$ & \\
\hline - & - & - & $\begin{array}{c}r \\
(\% r V / r V)\end{array}$ & $\begin{array}{c}f \\
(\% / r / / q)\end{array}$ & $\begin{array}{c}\wedge \\
(\% V Y / V Y)\end{array}$ & $\begin{array}{c}1 \\
(\% 9 / \cdot 9)\end{array}$ & $\begin{array}{c}1 . \\
(\% / 9 \cdot / 9 \cdot)\end{array}$ & $\mathrm{R}$ & سودوموناس \\
\hline - & - & - & $\begin{array}{c}r \\
(\% 19 / 94)\end{array}$ & $\begin{array}{c}1 \\
(\% / 9 / \cdot 9)\end{array}$ & $\begin{array}{c}1 \\
(\% / 9 / 9)\end{array}$ & $\begin{array}{c}1 \\
(\% / 9 / 9)\end{array}$ & $\begin{array}{c}1 \\
(\% / 9 / \cdot 9)\end{array}$ & I & \\
\hline$\%(\cdots)$ & $1(\% 1 \cdots)$ & - & $1(\% 1 \ldots)$ & $1(\% 1 \cdots)$ & $1(\% 1 \cdots)$ & $1(\%)$ & $1(\% 1 \cdots)$ & $\mathrm{S}$ & \\
\hline
\end{tabular}

\begin{tabular}{|c|c|c|c|c|c|c|c|c|c|}
\hline . & . & - & . & . & . & . & . & $\mathrm{R}$ & كلبسيلا بِنومونيه \\
\hline . & . & - & . & . & . & . & . & I & \\
\hline $1(\% 1 \cdots)$ & $1(\%)$ & . & $1(\% 1 \cdots)$ & $1(\% 1 \cdots)$ & $1(\%)$ & $1(\% 1 \cdots)$ & . & $\mathrm{S}$ & اشريشيا كلى \\
\hline . & . & $1(\% 1 \cdots)$ & . & . & . & . & $1(\% 1 \cdots)$ & $\mathrm{R}$ & \\
\hline . & . & . & . & . & . & . & . & I & \\
\hline $1(\% 1 \cdots)$ & $1(\%)$ & - & $1(\% 1 \ldots)$ & $1(\% 1 \cdots)$ & $1(\%)$ & $1(\% 1 \cdots)$ & . & $\mathrm{S}$ & \\
\hline . & . & - & . & . & . & . & $1(\% 1 \cdots)$ & $\mathrm{R}$ & هافنيا آلوئى \\
\hline . & . & - & . & . & . & . & . & $\mathrm{I}$ & \\
\hline$\cdot$ & $\Delta(\% \cdots)$ & - & $F(/ / \wedge \cdot)$ & $\Delta(\%)$ & $r(\% .9 \cdot)$ & $\Delta(\% 1 \cdots)$ & . & $\mathrm{S}$ & \\
\hline$\Delta(\%)$ & . & - & $1(\% / r)$ & . & $r\left(/ / F_{\cdot}\right)$ & . & $\Delta(\% 1 \cdots)$ & $\mathrm{R}$ & كلبسيلا آئروثنز \\
\hline . & . & - & . & . & . & . & . & I & \\
\hline
\end{tabular}

داده مىشود. نقش باكترىهاى بيمـارىزا بـه عنسوان يكى از علل سينوزيت ثابت شده است. بروز مقاومتهاى ميكروبس، درمـان بيمـارىهـاى عفـونى را مشـكل سـاخته اسـتـ و در

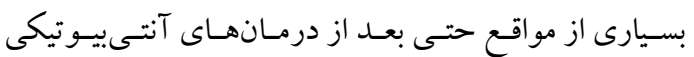
كسترده، شـاهد افز ايش طيـف وسـيعى از عفونست در بيمـار

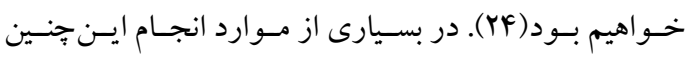
جراحىهايى زمينه ابتلا بيمار به بيمارىهـاى عفـونى سـينوس را بيشتر مى كند؛ بنابر اين شناسايى عو امل عفونى و روشهاى مناسب درمان در اين مورد حائز اهميت است؛ بنابراين نقش

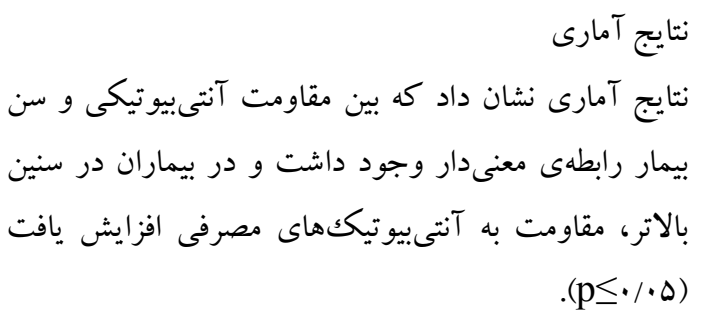

سينوزيت مزمن بيمـارى شـايعى اسـت كه در كلينيككهـا و

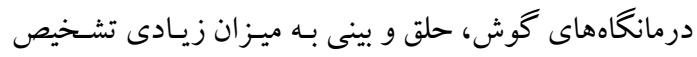


ميكروبى ممكن است آلوده شود. جداسازى و شناسايى اين

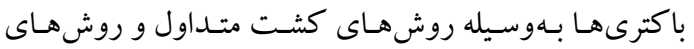
تشخيصى باكترىشناسى امكانيذير است(YA،YY). همجنين در بعضى از بيمـاران مبتلا بـه رينوسـينوزيت مـزمن افرادى دجار فلور ميكروبـى نامتعادل در زيست بـوم ميكروبى يـا ديس بيوسيس ميكروبيوم هستند. كاهش تنوع يكك گونسه يـا

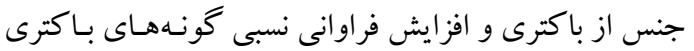

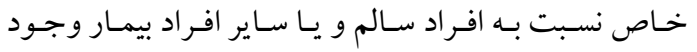

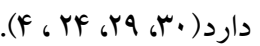
همجنين در مطالعه Rezai و همكارانش (ها •Y)، بيشترين

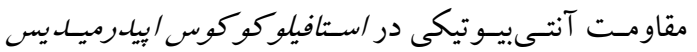

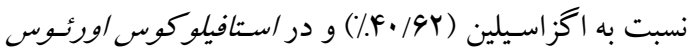
نسبت به آمو كسى سيلين، آمبىسيلين و اكزاسيلين (هر كـدام

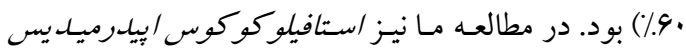

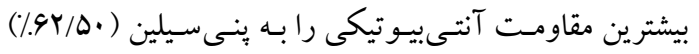

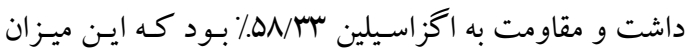
نسـبت مطالعـه Rezai و همكــارانش (ها •r) بيشـتر بـود.

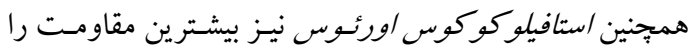

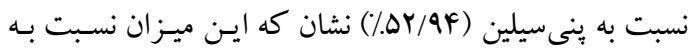

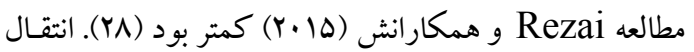
باكترىها از يكك بيمار به بيمار ديخر يـا همـراه بيمـار، انتقـال

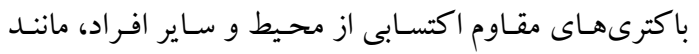

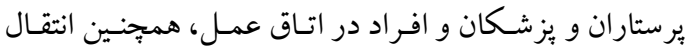

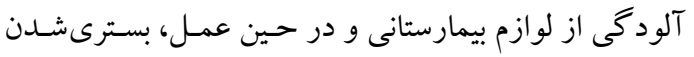

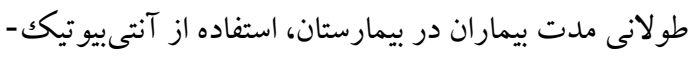
هاى وسيع الطيف و توليد كننده آنزيمهاى بتالاكتاماز، كنترل

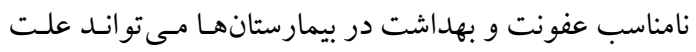

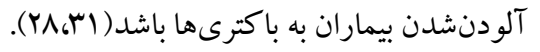
Bhattacharyya بيمـاران يسس از عمـل جراحسى آندوسـكويى سينوسىى،

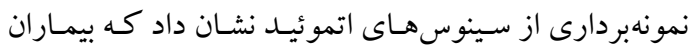

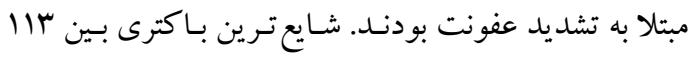

و ارتباط باكترىها و تعيين مقاومت آنتىبيو تيكى و كاربرد

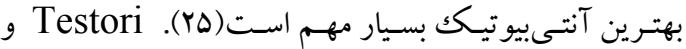

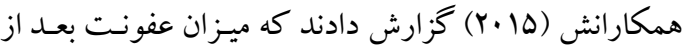

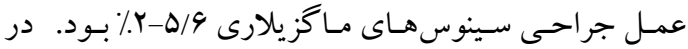

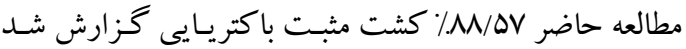
كه از مطالعه Testori بيشتر بـود(Y). در تحقيق Hsuو H

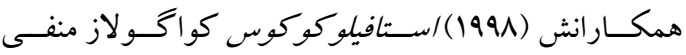

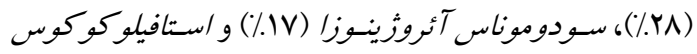

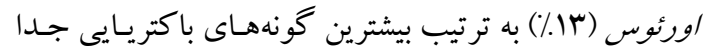
شده از بيماران مبتلا به رينوسينوزيت مـزمن و • •هـ از سـويههاى سودوموناس آئروثينوزا مقاوم بـه كينولون بودنـد (YV). در مطالعه حاضر ميزان/ستافيلوكوكوس /ورئسوس

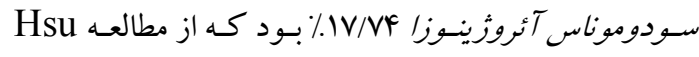

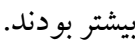
Rezai مزمن را تحت بررسى قرار دادند. فراوانى باكترىهاى توليد-

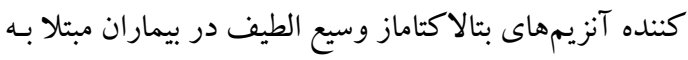

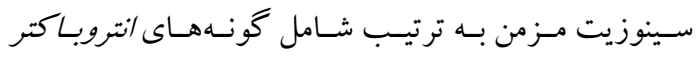

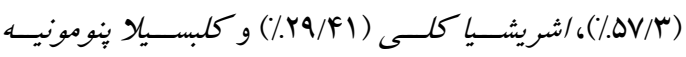

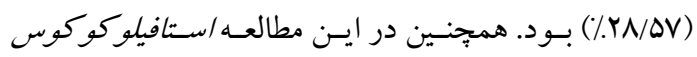

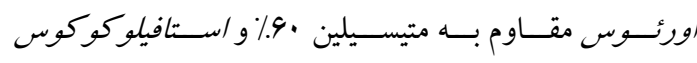

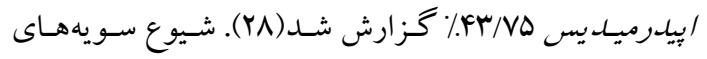

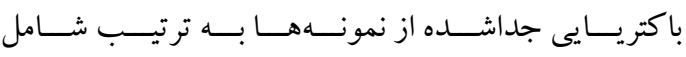

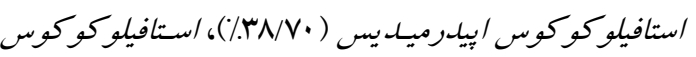

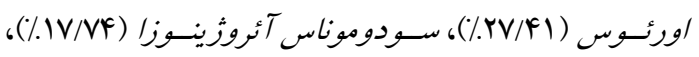

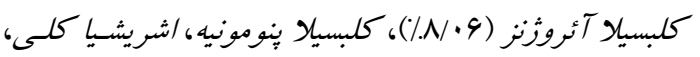

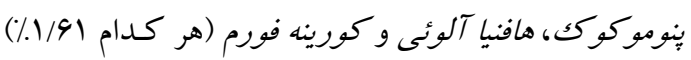

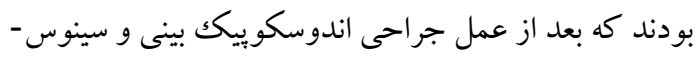

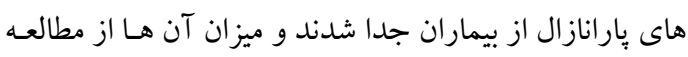
Rezai

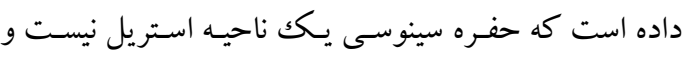
توسط گونسهــاى مختلـف بـاكترىهـا و تشـكيل بيـوفيلم 
بيو تيـك ينـى ســـلين ( •9٪\%) و بيشـترين حساسـيت نسـبت

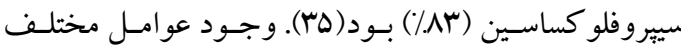

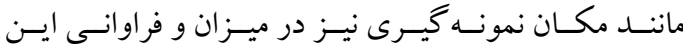
باكترىهاى در مطالعات مختلف متفاوت است. بهطور مثال سينوسهاى ماكزيلارى، سينوس هاى اتموئيد و سينوسهـاى فرونتال هر كدام جمعيـت ميكروبـى خـاص خـود راد دارنـــ و .

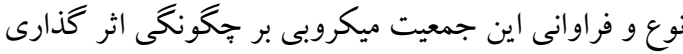

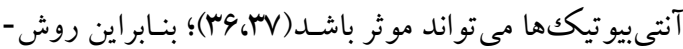

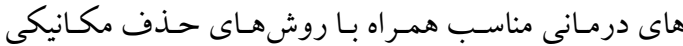

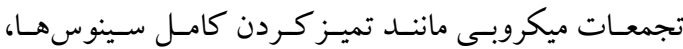
ييشخيرى از ايجاد آلودگى حين عمل و استفاده مناسـب از

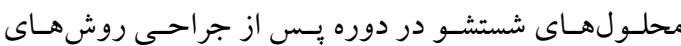
مناسب جهت كاهش جمعيت ميكروبى است(ش人). در مطالعه حاضر تعداد نمونه كم بود و همجرنين ممكن اسـت آلود گى در حين نمونه گيرى و در آزمايشگاه علت به وجـود آمدن نتايج كاذب شود؛ اما با توجه به اينكه تعداد بيماران بـا جراحسى سـينوس و عفونـت آنهـا محسدود اسـت؛ بنـابراين مطالعه روى آنهاو انتخاب روش مناسب درمـانى بـه همـراه يايش دورهاى اين بيمار ان با اهميت است. از طرف ديخر، بـا توجه به اينكه آنتىبيو تيككهـاى بكـار رفته در ايسن مطالعـه مطابق با استاندارد CLSI انتخـاب شـده بودنـــ، ايسن انتظـار مىرود كه نتايج اين تحقيق بتواند به بزشكان كمكك كنـد تـا با در نظر كرفتن نوع باكترى كرم مثبـت يـا منفى و انتخـاب

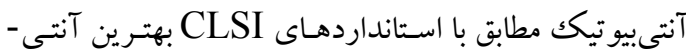
بيو تيك را تجويز نمايند. در اين تحقيق بيماران مراجعه كننده به بيمارستان تخصصى گوش، حلق و بينى استان گيلان مورد

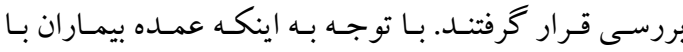
بيمارىهاى مرتبط با كوش، حلـق و بينى بـه ايـن بيمارسـتان مراجعه مى كنند؛ بنابر اين نتايج ايـن تحقيـق مسىتوانــ نشـان

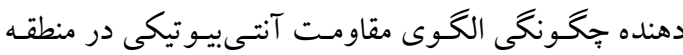

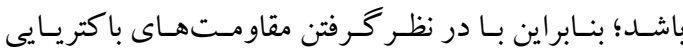
كزارش شده در اين تحقيق مىتوان بهترين آنتىبيوتيـك كـه
بيمار، /ستافيلوكوكوس /ورئوس ( أ|٪) بود(Yץ). همجنين در مطالعه Rom و همكار انش (19 (r) انجـام شـد، شـايع تـرين

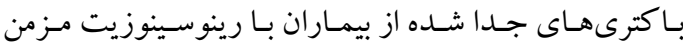
كورينه باكتريوم (9Y\%) و /ستافيلوكوكوس /ورئسوس (19٪)

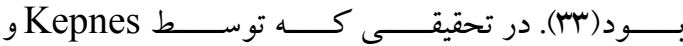
V• Bhattacharyya

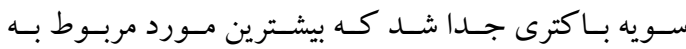
استافيلوكوكوس /ورئوس (19٪) بود كه از مطالعه مـا كمتر

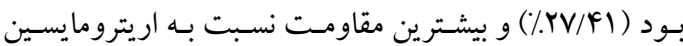

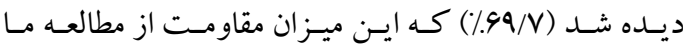

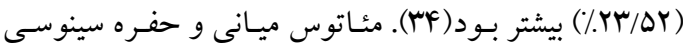
شامل اكسـيد نيتريـك در بخـش كَازى سـينوس مسىباشــ، همجينين بروتئين /يِيتيدهاى ضـد ميكروبسى در مـايع سينوسى وجود دارند كه بر ميز ان باكترىهاى بيمارىزا در اين بخش

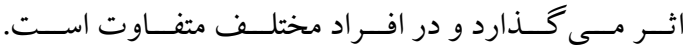
استافيلوكو كوس اورئوس جز فلور نرمال بينى به حساب مى آيد (اگر ميز ان آن .... إحد تشكيلدهنده كلـونى /ميلـى ليتر بيشتر باشد بيمارىزا اسـت)؛ بنـابراين در اكثـر مطالعـات ميـزان ايسن بـاكترى از سـاير بــاكترىهـا بيشـتر اسـتـ(هـ). جداسازى و كشت باكترىهـا و انجـام تسـت آنتىبيـوتيكى روش مناسب و به صرفه جهت تشخيص بهترين آنتىبيوتيك و كاربرد آن در درمان بيمار است(هس، (WF). Brook و همكار انش (19 19) گز ارش دادند كه در بيمـاران

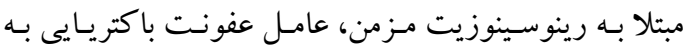
ترتيــب اســـافيلو كو كوس اورئسـوس (YF-YF)

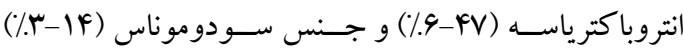
بودند كه بهطور كل ايسن ميزان فراوانى از مطالعـه مـا كمتر

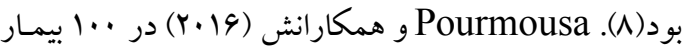
مبـتلا بـه رينوسـينوزيت مـزمن نشـان دادنـــ كـه شـايع تـرين

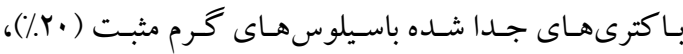
استافيلو كو كوس كو اكولاز منفى (19\%) و استافيلو كو كوس اورئسوس (هاء)) بودنـد. بيشـتر ين مقاومـت نسـبت بـه آنتى - 


$$
\begin{aligned}
& \text { مقاومت آنتىبيو تيكى مؤثر است؛ با توجه به اين كه تحقيق } \\
& \text { باكترى به آن حساس اسـت يـا مقاومـت كمترى دارد را بـهـ } \\
& \text { حاضر در بيمارستان تخصصى گَوش، حلق و بينى استان } \\
& \text { عنوان درمـان اوليه در نظـر بخيرنـد و از تجويز غير منطقى } \\
& \text { انجام شد، نتايج اين تحقيق مىتو اند به يز شكان منطقه كمك ديف } \\
& \text { آنتىبيوتيك،، تجويز آنتىبيوتيككهايى كه باكترى جدا شـده }
\end{aligned}
$$

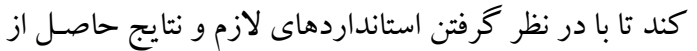

$$
\begin{aligned}
& \text { از بيمـار بـهـ آن مقاومـت ذاتى داردو و تجـويز بـدون در نظـر }
\end{aligned}
$$

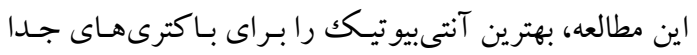

$$
\begin{aligned}
& \text { كرفتن استانداردهاى لازم خوددارى شود. اميـد است بـادئ } \\
& \text { شده انتخاب كنند و تجويز بدون در نظر گرفتن استاندارد- }
\end{aligned}
$$

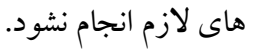

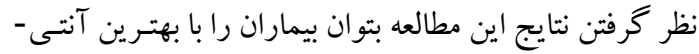

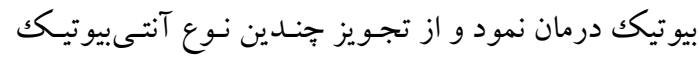

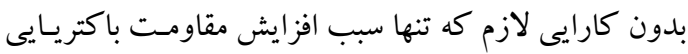

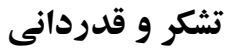

$$
\begin{aligned}
& \text { و تشديد عفونت مى شوند جلو گيرى كرد. } \\
& \text { بدين وسيله از معاونت تحقيقات و فناورى دانشگاه علوم } \\
& \text { يزشكى گَلالن جهت حمايتهاى مادى و معنوى قدردانى } \\
& \text { مىشود (شماره ثبت بايان نامه:ابآ، كد اخلاق: } \\
& .(19 r \cdot 0 \cdot 94 \cdot 4 \\
& \text { نتيجه كيرى }
\end{aligned}
$$

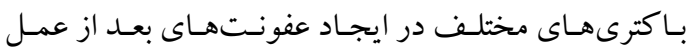

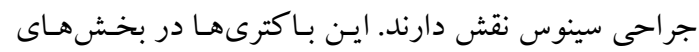

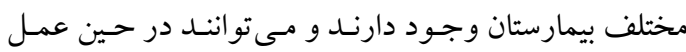

$$
\begin{aligned}
& \text { جر احى نيز منتقل شوند؛ بنابراين رعايت اصسول بهداشتى درد }
\end{aligned}
$$

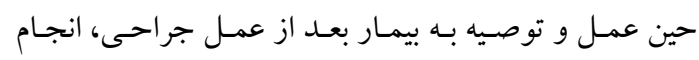

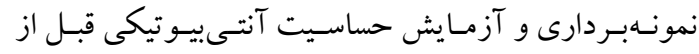

$$
\begin{aligned}
& \text { تجويز آنتىبيوتيكك در انتخـاب صسحيح درمـان و كـاهش ونش }
\end{aligned}
$$

1. Scadding GK, Durham SR, Mirakian R, Jones NS, Drake-Lee AB, Ryan D, et al. BSACI guidelines for the management of rhinosinositis and nasal polyposis. Clin Ex Allergy. 2008;38(2):260-75.

2. Nemati S, Jafari Shakib R, Shakiba M, Araghi N, Azimi SZ. Allergic rhinitis in adults with chronic suppurative otitis media. Iran J Otorhinolaryngol. 2015;27(81):261-6.

3. Sivasubramaniama R, Douglasb R. The microbiome and chronic rhinosinusitis. World J Otorhinolaryngol Head Neck Surg. 2018;4(3):216-21.

4. DeConde AS, Soler ZM. Chronic rhinosinusitis: epidemiology and burden of disease. Am J Rhinol Allergy. 2016;30(2):134-9.

5. Naderian M, Mohammadi A. Evaluation of diseases with symptoms similar to chronic sinusitis, Booali hospital, Tehran, 2009-2010. RJMS. 2011;17 (80 and 81):34-9. [In Persian]

6. Meymane Jahromi A, Shahabi Pour A. The Epidemiological and clinical aspects of nasal polyps that require surgery. Iran J Otorhinolaryngol. 2012;24(67):75-8.

7. Mustafa M, Patawari P, Iftikhar H, Shimmi SC, Hussain SS, Sien M. Acute and chronic rhinosinusitis, pathophysiology and treatment. Int J Pharm Sci Invent. 2015;4(2):30-6.

8. Brook I. Chronic sinusitis in children and adult: role of bacteria and antimicrobial management. Curr Allergy Asthma Rep. 2005;5(6):482-90.

9. Platts-Mills TA, Rosenwasser LJ. Chronic sinusitis consensus and the way forward. J Allergy Clin Immunol. 2004;114(6):1359-61. 


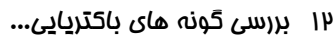

10. Farhadi M, Moshrefi M. Functional endoscopic sinus surgery report of 200 cases. RJMS. 1995;2(1995):127-38. [In Persian]

11. Weber RK, Hosemann W. Comprehensive review on endonasal endoscopic sinus surgery. GMS Curr Top Otorhinolaryngol Head Neck Surg. 2015;14(2015):Doc08.

12. Yan R, Zhang X. Analysis of complications in functional endoscopic sinus surgery. Lin Chuang Er Bi Yan Hou Ke Za Zhi. 2003;17(8):456-7.

13. Rezai MS, Pourmousa R, Dadashzadeh R, Ahangarkani F. Multidrug resistance pattern of bacterial agents isolated from patient with chronic sinusitis. Caspian $\mathrm{J}$ Intern Med. 2016;7(2):114-9.

14. Gerami H, Banan R, Nemati SH, Fallahi AA, Mojtahedi A, Soltanipour S, et al. The Relative frequency of allergic fungal rhinosinusitis in patients with nasal polyposis in Rasht City, Iran. Qom Univ Med Sci J. 2017;10(12):45-53. [In Persian]

15. Farokhpey F, Niabati N, Amri Maleh M, Omraninava M, Mansoursaravi M, Maleh M, et al. Comparison efficacy of doxycycline and azithromycin and clarithromycin in the treatment of chronic bacterial rhinosinusitis. MUMS. 2018;57(7):814-21. [In Persian]

16. Hashemian F, Farahani F. Frequency of nasal polyposis in chronic rhinosinusitis and role of endoscopic examination in correct diagnosis. Avicenna J Clin Med. 2005;12(3):20-3. [In Persian]

17. Husain S, Amilia HH, Rosli MN, Zahedi FD, Sachlin IS. Development group clinical practice guidelines management of rhinosinusitis in adolescents \& adults. management of rhinosinusitis in adults in primary care. Malays Fam Physician. 2018;13(1):28-33.

18. Sharp SE, Searcy C. Comparison of mannitol salt agar and blood agar plates for identification and susceptibility testing of Staphylococcus aureus in specimens from cystic fibrosis patients. J Clin Microbiol. 2006;44(12):4545-6.

19. Zimbro MJ, Power DA, Miller SM, Wilson GE. Handbook of microbiological culture media. 2 nd ed. Maryland: USA, 2009: 50-51, 112-3, 114, 222-3.

20. Forbes BA. Sahm DF, Weissfeld AS. Bailey and Scott's diagnostic microbiology. 12nd ed. New York: Elsevier, 2007: 258-9, 272-5, 471-2.

21. Taheri JB, Fallah F, Maleki Z, Oosia MA. The relationship between halitosis and gramnegative anaerobic bacteria in oral cavity. Beheshti Univ Dent J. 2005;22(4):633-43. [In Persian]

22. Carroll KC, Hobden JA, Miller S, Morse SA, Mietzner TA, Detrick B, et al. Jawetz, Melnick, \& Adelberg's medical microbiology. 27nd ed. New York: McGraw-Hill, 2016: 194.

23. Clinical and laboratory standards institute (CLSI). M100, Performance standards for antimicrobial susceptibility testing. 28nd ed. Wayne: Clinical and laboratory standards institute; 2018:30-40, 54-61, 77-80.

24. Gupta V, Gupta A. Prevalence and clinical profile of patients with chronic fungal maxillary sinusitis. Int J Otorhinolaryngol Head Neck Surg. 2019;5(2):280-4.

25. Naeimi M. Combined septorhinoplasty and functional endoscopicsinus surgery. IJORL. 2007;19(2007):83-8. [Persian]

26. Testori T, Drago L, Wallace SS, Capelli M, Galli F, Zuffetti F, et al. Prevention and treatment of postoperative infections after sinus elevation surgery: clinical consensus and recommendations. Int J Dent. 2012;2012(2012):365809.

27. Hsu J, Lanza DC, Kennedy DW. Antimicrobial resistance in bacterial chronic sinusitis. Am J Rhinol. 1998;12(4):243-8.

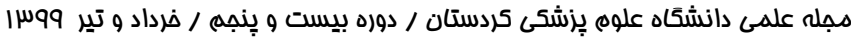


28. Rezai MS, Pourmousa R, Dadashzadeh R, Ahangarkani F. Multidrug resistance pattern of bacterial agents isolated from patient with chronic sinusitis. Caspian J Intern Med. 2016;7(2):114-9.

29. Lee JT, Frank DN, Ramakrishnan V. Microbiome of the paranasal sinuses: update and literature review. Am J Rhinol Allergy. 2016;30(1):3-16.

30. Bose S, Grammer LC, Peters AT. Infectious chronic rhinosinusitis. J Allergy Clin Immunol Pract. 2016;4(4):584-9.

31. Andersson DI, Hughes D. Selection and transmission of antibiotic-resistant bacteria. Microbiol Spectr. 2017;5(4):MTBP-0013-2016.

32. Bhattacharyya $\mathrm{N}$, Gopal HV, Lee KH. Bacterial infection after endoscopic sinus surgery: a controlled prospective study. Laryngoscope. 2004;114(4):765-7.

33. Rom D, Bassiouni A, Eykman E, Liu Z, Paramasivan S, Alvarado R, et al. The association between disease severity and microbiome in chronic rhinosinusitis. Laryngoscope. 2019;129(6):1265-73.

34. Bhattacharyya N, Kepnes LJ. Assessment of trends in antimicrobial resistance in chronic rhinosinusitis. Ann Otol Rhinol Laryngol. 2008; 117(6):448-52.

35. Pourmousa R, Dadashzadeh R, Ahangarkani F, Rezai MS. Frequency of bacterial agents isolated from patients with chronic sinusitis in Northern Iran. Glob J Health Sci. 2015;8(5):239-46.

36. Juan F, Ayiheng Q, Yuqin F, Hua Z, Jun Y, Bin H. Risk factors of chronic rhinosinusitis after functional endoscopic sinus surgery. Med Sci Monit. 2017;23(2017):1064-8.

37. Drago L, Pignataro L, Torretta S. Microbiological aspects of acute and chronic pediatric rhinosinusitis. J Clin Med. 2019;8(2):149.

38. Principi N, Esposito S. Nasal irrigation: an imprecisely defined medical procedure. Int J Environ Res Public Health. 2017;14(5):pii: E516. 